ISSN 1818-1295 elSSN 2616-6194

REPORTS OF MORPHOLOGY
$\begin{gathered}\text { Official Journal of the Scientific Society of Anatomists, } \\ \text { Histologists, Embryologists and Topographic Anatomists } \\ \text { of Ukraine } \\ \text { journal homepage: https://morphology-journal.com }\end{gathered}$

\title{
Morphological changes in the heart of rats after serial intravesical administration of Doxorubicin
}

Kostiuk O.H.', Hodovan N.L.', Gormash P.P. ${ }^{2}$, Taran I.V. ${ }^{1}$, Grebeniuk D.I. ${ }^{1}$, Mashevska O.V. ${ }^{1}$

${ }^{1}$ National Pirogov Memorial Medical University, Vinnytsya, Ukraine

${ }^{2}$ Utility non-profit enterprise "Vinnitsa Regional Pathological Bureau of Vinnitsa Regional Council", Vinnytsya, Ukraine

\section{ARTICLE INFO}

Received: 16 November 2020

Accepted: 6 January 2021

UDC: $616-006: 615.277 .3+591.412+$ 59.089

\section{CORRESPONDING AUTHOR}

e-mail: scienceandroid@gmail.com Taran I.V.

\begin{abstract}
Along with a pronounced antitumor effect, Doxorubicin causes systemic effects with damage to vital organs, including the heart. It prompts the search for ways to prevent the cardiotoxic effect of the drug, one of which could be its intravesical administration. The aim of the study was to develop a method of serial intravesical administration of Doxorubicin in medium therapeutic doses in an experiment and to evaluate the cardiotoxic effect of the drug. 42 female Wistar rats were included in the study. The control group consisted of 7 intact rats. The experimental group consisted of 35 rats who received intravesical chemotherapy with Doxorubicin at a dose of $5 \mathrm{mg} / \mathrm{kg}$ once a week for 5 weeks. On days 7th, 14th, 21st, 28th, 35th the hearts of experimental animals were taken for morphological examination. Histomorphometrically determined: the diameter of cardiomyocytes (in the middle part) and the transverse diameter of their nucleus, the width of the interstitial space (endo- and perimysium). The data of histomorphological and histomorphometric examination of the myocardium testified that all animals of the experimental group had a circulatory disorder in the heart muscle at the level of hemomicrocirculation. Such changes led to cardiomyocyte hypotrophy, interstitial edema and fibrosis. During intravesical chemotherapy, the animals showed marked changes in the myocardium, such as expansion of the endomysial zone, due to capillary congestion and edema, in comparison with animals of the intact group. At the end of the experiment, the animals of the experimental group retained the expansion of the endomysial zone, mainly due to interstitial fibrosis. Such changes indicate myocardial hypoxemia with damage and death of cardiomyocytes, activation of interstitial and replacement collagen formation. The obtained morphological data partially indicate the development of dilated cardiomyopathy in experimental animals. However, these changes were less pronounced than the previously described changes that occur after systemic administration of the drug. Additional studies of the electrophysiological activity of the heart and biochemical markers will make it possible to fully assess the degree of cardiotoxicity of Doxorubicin after its intravesical administration. Thus, serial intravesical administration of Doxorubicin in moderate therapeutic doses according to the proposed method causes changes in the myocardium of experimental animals, which are partially similar to the changes in the heart of people receiving chemotherapy with this drug.
\end{abstract}

Keywords: Doxorubicin, cardiomyopathy, morphology, experiment, rats, intravesical.

\section{Introduction}

Due to the tendency to a constant increase in overall morbidity and mortality, bladder cancer remains an urgent problem of modern medicine in general and oncology in particular [10, 16].

Bladder cancer ranks fourth in the structure of oncopathology in the United States and Europe. In terms of mortality, this pathology ranks seventh and eighth in the structure of mortality from tumor diseases in the United States [18] and Europe, respectively [4]. Men suffer from bladder cancer about 3-4 times more often than women. According to statistics, every 26th man will develop bladder cancer during his lifetime [18]. At the same time, the overall five-year survival rate in Europe is about 68\% [2].

Due to the constant improvement of diagnostic 
algorithms, more and more newly diagnosed cases (up to $75 \%$ according to some data) are superficial bladder cancer, when the tumor affects only the mucous membrane or submucosal layer [1].

Transurethral resection of the tumor is a common standard in the treatment of patients with superficial bladder cancer [12, 22]. Intravesical chemotherapy and/or immunotherapy are used as adjuvant therapy after transurethral resection to prevent the development of residual and recurrent neoplasms [17, 25].

The intravesical route of drug administration opens wide opportunities for scientists and practitioners to develop new and optimize existing treatments for non-invasive bladder cancer $[17,25]$. One such optimization method is intravesical administration of Doxorubicin, which has proven itself in systemic administration [5], although it has led to the development of Doxorubicin-induced cardiomyopathy $[7,9,15,21]$.

Given the morphological features of the structure of the mucous membrane of the bladder, the absorption of the chemotherapy into the systemic bloodstream, and accordingly its systemic effects should be minimal [8, 20].

However, this problem requires large-scale studies, including a preclinical study of the cardiotoxicity of Doxorubicin by intravesical administration.

The aim of the study was to develop a method of serial intravesical administration of Doxorubicin in moderate therapeutic doses in the experiment and to evaluate the cardiotoxic effect of the drug.

\section{Materials and methods}

The experimental study was performed on the basis of a research laboratory of preclinical study of pharmacological substances of National Pirogov Memorial Medical University, Vinnytsya.

All experiments were performed in accordance with the "Regulations on the use of animals in biomedical experiments" with the permission of the Bioethics Committee and in accordance with the provisions of Directive 2010/63/ EU of the European Parliament and of the Council of 22 September 2010 "On the protection of animals used for scientific purposes".

The study included 42 female Wistar rats under 1 year of age and weighing 120.0 to 220.0 grams (192.0 15.2 grams).

The control group consisted of 7 intact rats, which were selected to determine the main studied morphological and morphometric parameters in the norm. The experimental group consisted of 35 rats who underwent intravesical chemotherapy with Doxorubicin according to the author's method (Patent of Ukraine for utility model № 138090 from 25.11.2019).

The technique consisted of intravesical administration of Doxorubicin at a dose of $5 \mathrm{mg} / \mathrm{kg}$ once a week for 5 weeks. The dose of $5 \mathrm{mg} / \mathrm{kg}$ was determined by recalculating the average therapeutic dose of the drug for humans in the treatment of superficial bladder cancer. The recalculation was performed according to the method proposed by A.B. Nair and Sh. Jacob (2016) [13].

Direct administration of the drug into the bladder was performed according to the author's method - a method of serial intravesical administration of drugs in female rats (Patent of Ukraine for utility model № 138092 from 25.11.2019) using a special catheter (Patent of Ukraine for utility model № 139761 from 27.01 .2020$)$. The catheter is a flexible tube with a diameter of $2 \mathrm{Fr}(0.67 \mathrm{~mm})$ and a length of $20 \mathrm{~mm}$, at one end of which is an oil with a diameter of 6 $\operatorname{Fr}(2.0 \mathrm{~mm})$, which does not cover the lumen of the catheter. The catheter was inserted into the bladder and drugs were administered as follows. Under general anesthesia, a lowermiddle laparotomy was performed in experimental rats. The body of the bladder was removed into the surgical wound. A longitudinal cystotomy $3 \mathrm{~mm}$ long was performed. Antegradely conducted the tubular part of the catheter through the inner opening of the urethra through the urethra to the outside. The bladder was sutured. Performed revision of the abdominal cavity and washing it with an antiseptic solution. The laparotomy wound was sutured tightly in layers.

To prevent the cytostatic effect of Doxorubicin on the wound surface, its administration was started one week after catheter placement, when there was a complete restoration of the integrity of the bladder wall. To administer Doxorubicin, the tubular part of the catheter located in the outer opening of the urethra was fixed with tweezers. The syringe needle was inserted into the catheter hole and the drug was injected into the bladder.

One week after each administration of the drug $(7,14$, $21,28,35$ days), 7 rats were randomly selected and removed from the experiment by dislocation of the cervical vertebrae under ketamine anesthesia at the rate of $0.22 \mathrm{ml}$ per 100 grams of weight of the experimental animal.

After dissection, the heart was removed, followed by fixation in $10 \%$ neutral formalin solution. After fixation for 3 days, cardiac samples were prepared according to standard methods. Paraffin sections 5-7 $\mu \mathrm{m}$ thick were stained with hematoxylin and eosin. Microscopy and photographing of histological specimens were performed using a light microscope OLIMPUS BX 41 at magnifications of 40, 100, 200, 400 and 1000. Microscopy assessed the condition of the myocardium, the presence and nature of pathological and compensatory-adaptive changes in it.

Image acquisition and processing, as well as morphometry were performed using the program "Quick PHOTO MICRO 2.3". Histomorphometrically determined: the diameter of cardiomyocytes (in their middle part) and the transverse diameter of their nucleus, the width of the interstitial space (endo- and perimysia).

The obtained data were processed using the statistical software package SPSS 20.0 for Windows.

\section{Results}

The results of microscopic examination of the myocardium of the control group of animals are described 


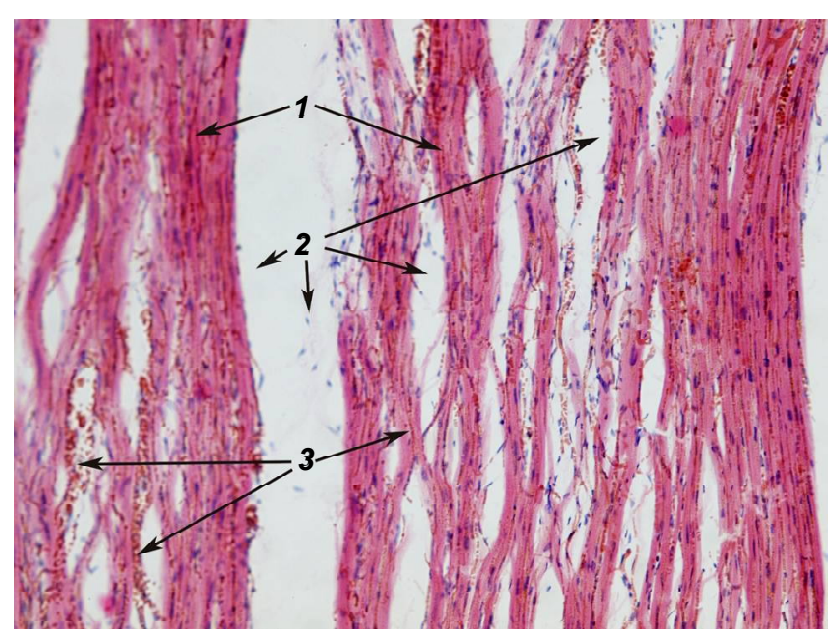

Fig. 1. The myocardium of the experimental group rat on day 7 after intravesical chemotherapy. Hematoxylin-eosin. x200. 1 cardiomyocytes; 2 - edema of the interstitium; 3 - dilated and fullblooded vessels of hemomicrocirculation.

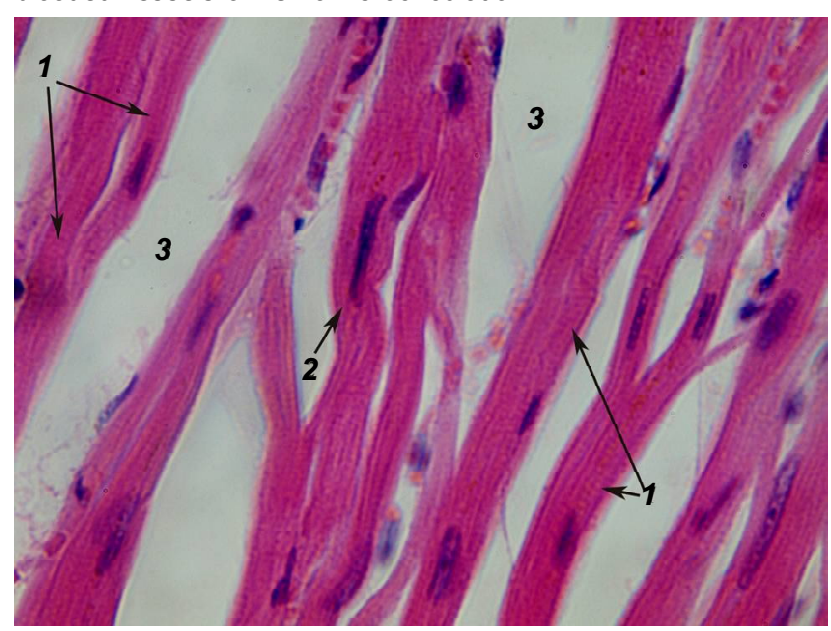

Fig. 2. The myocardium of the experimental group rat on day 7 after intravesical chemotherapy. Hematoxylin-eosin. x1000. 1 cardiomyocytes with a clear striation; 2 - wavy tortuous cardiomyocyte; 3 - endomysium edema.

by us in a previous work [7].

Microscopically on the 7 day of the experiment in the group of animals treated with intravesical chemotherapy, the most typical were unevenly expressed disorders of hemomicrocirculation in the myocardium. Namely: capillaries and postcapillary venules had unevenly expanded lumen, signs of plethora, erythrostasis and erythrocyte sludge (in capillaries). Uneven edema of the myocardial stroma was detected. The width of the peri- and endomysium was $29.20 \pm 0.30 \mu \mathrm{m}$ and $5.710 \pm 0.130 \mu \mathrm{m}$, respectively (Fig. 1). The average diameter of cardiomyocytes was $11.04 \pm$ $0.14 \mu \mathrm{m}$. In general, cardiomyocytes had a normal structure, a pronounced transverse striation. There were only single muscle fibers with eosinophilic homogenization and vacuolation of the sarcoplasm, basophilia and nuclear pyknosis, or enlightened sarcoplasm. These changes were mainly observed in the muscle fibers of the subendocardial zone (Fig. 2). The transverse diameter of the nuclei averaged $3.520 \pm 0.170 \mu \mathrm{m}$.

Histomorphologically on the 14 day of the experiment in the group of animals treated with intravesical chemotherapy, there were signs of uneven swelling of the myocardial stroma (mainly endomysia). Thus, the width of the peri- and endomysium was $31.80 \pm 0.40 \mu \mathrm{m}$ and $5.920 \pm 0.110 \mu \mathrm{m}$, respectively. In the vessels of hemomicrocirculation there was an uneven blood supply there were areas with moderate capillary-venular hyperemia (sometimes with signs of erythrostasis) with anemic vessels. The average diameter of cardiomyocytes was $10.83 \pm 0.15 \mu \mathrm{m}$, the diameter of the cross section of the nuclei $-3.420 \pm 0.130 \mu \mathrm{m}$. In general, cardiomyocytes had a normal structure, a pronounced transverse striation, in areas with severe endomysium edema clearly manifested between them anastomoses. However, there were both single muscle fibers and small groups with eosinophilic homogenization (or uneven enlightenment) and vacuolation of sarcoplasm, basophilia, and nuclear pyknosis, not clearly visualized striation. These changes were observed mainly in the muscle fibers of the subendocardial zone and in areas with anemic vessels of hemomicrocirculation (Fig. 3).

At the histological level on the 21 day of the experiment in the myocardium of animals undergoing intravesical chemotherapy, similar to the previous period of the experiment there were dyscirculatory changes in the form of uneven interstitial edema (peri- and endomysial width averaged $30.97 \pm 0.51 \mu \mathrm{m}$ and $5.8700 .080 \mu \mathrm{m}$, respectively), uneven blood supply to the vessels of hemomicrocirculation and severe dilatation of lymphatic vessels perimysia, without signs of lymphostasis (Fig. 4). On average, cardiomyocytes had a diameter of $10.56 \pm 0.21 \mu \mathrm{m}$, and the cross-sectional diameter of the nuclei was $3.290 \pm 0.140 \mu \mathrm{m}$. Along with the vast majority of cardiomyocytes of normal histological

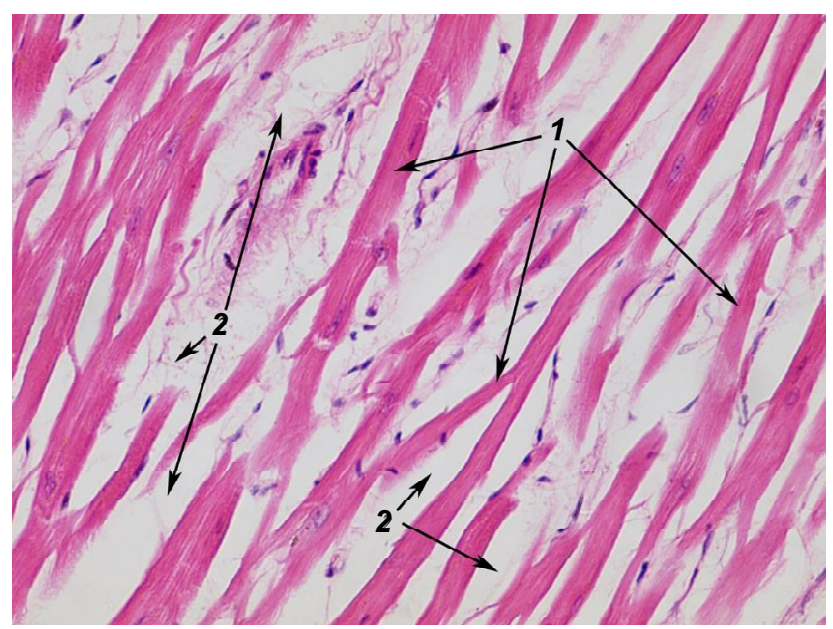

Fig. 3. The rat myocardium of the experimental group on the 14 day after intravesical chemotherapy. Hematoxylin-eosin. x400. 1 cardiomyocytes with indistinct striation; 2 - edema of the interstitium on the background of general anemia of the microcirculatory vessels. 


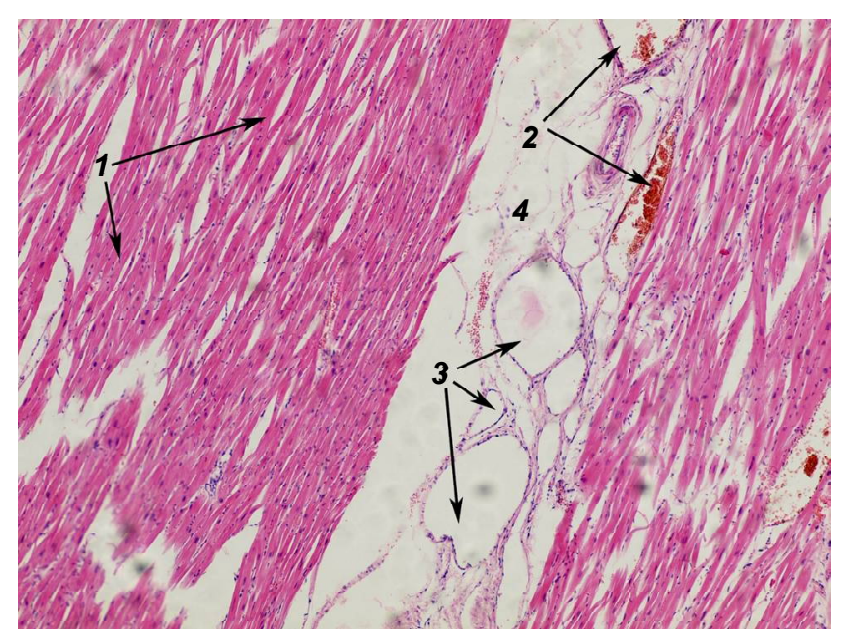

Fig. 4. The rat myocardium of the experimental group on the 21 day after intravesical chemotherapy. Hematoxylin-eosin. x100. 1 cardiomyocytes; 2 - dilated and full-blooded vessels of hemomicrocirculation; 3 - dilated lymphatic vessels; 4 - edema of the perimysium.

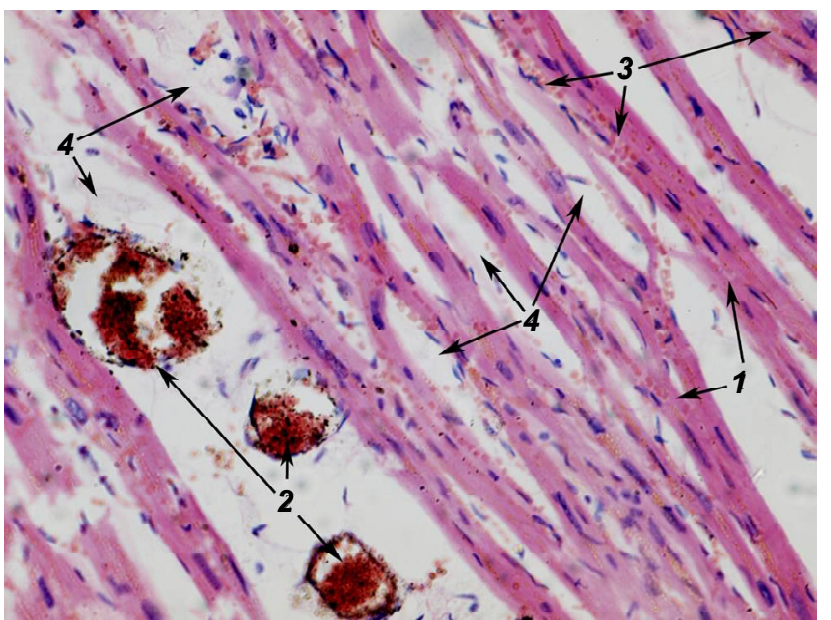

Fig. 5. The rat myocardium of the experimental group on the 28 day after intravesical chemotherapy. Hematoxylin-eosin. x400. 1 cardiomyocytes; 2 - dilated and full-blooded venules with erythrostasis; 3 - moderate plethora of capillaries; 4 - edema of the interstitium.

structure, muscle fibers with indistinct transverse striation, violation of the tinctorial properties of sarcoplasm (eosinophilic homogenization or its enlightenment) were observed. and vacuolation of sarcoplasm, basophilia, and pyknosis of the nucleus, not clearly visualized striation.

On the 28 day of the experiment in the myocardium of animals undergoing intravesical chemotherapy, the most characteristic were hemocirculatory disorders. Namely, uneven venular (mostly) and capillary plethora, somewhere with signs of stasis, as well as moderate interstitial edema (width of the peri- and endomysium was $30.53 \pm 0.18 \mu \mathrm{m}$ and $5.850 \pm 0.050 \mu \mathrm{m}$, respectively). Small clusters of active fibroblasts and foci of fibrosis were found in the stroma in some places. At the same time, there were no phenomena of lymphostasis, noticeable dilation of lymphatic vessels, as in the previous term (Fig. 5). On average, cardiomyocytes had a diameter of $10.21 \pm 0.21 \mu \mathrm{m}$, and the cross-sectional diameter of the nuclei was $3.400 \pm 0.100 \mu \mathrm{m}$. Among the muscle fibers of normal histological structure, there were focal fibers with indistinct transverse striation on the background of eosinophilic homogenization of sarcoplasm, uneven perception of basic stain, pyknosis or karyolysis (Fig. 6).

On the 35 day of the experiment, in the group of animals with intravesical chemotherapy, at the optical level in the myocardium there was a relatively uniform moderate blood supply to the vessels of hemomicrocirculation, local interstitial edema with dilated lymphatic vessels. The latter were observed in areas where there was excessive growth of loose unformed fibrous tissue, including endomysia. The fibrous structures of the fibrous tissue were relatively dense in places, directed mainly along the muscle fibers

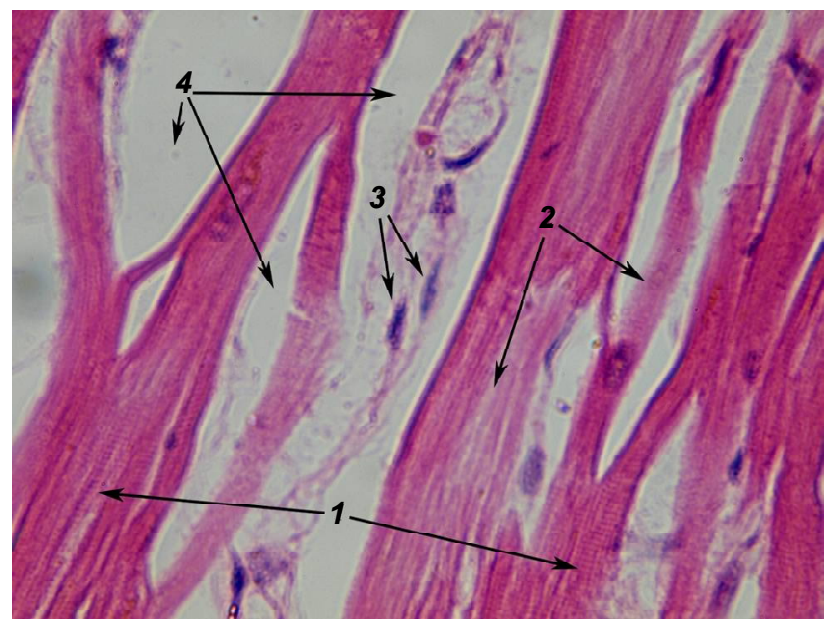

Fig. 6. The rat myocardium of the experimental group on the 28 day after intravesical chemotherapy. Hematoxylin-eosin. x1000. 1 - cardiomyocytes with a clear striation; 2 - cardiomyocytes with enlightened sarcoplasm; 3 - active interstitial fibroblasts; 4 - edema of the stroma.

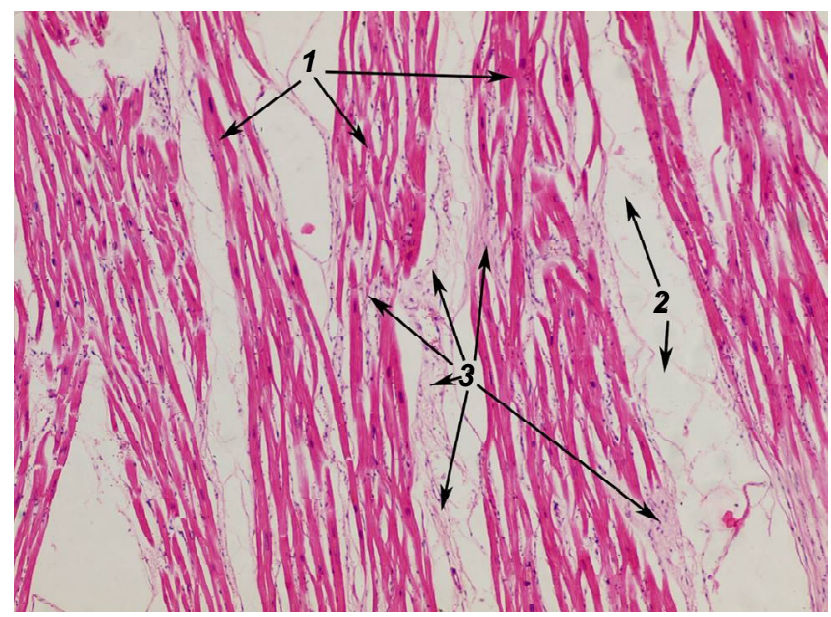

Fig. 7. The rat myocardium of the experimental group on the 35 day after the application of intravesical chemotherapy. Hematoxylineosin. x100. 1 - muscle fibers; 2 - edema of the stroma; 3 - interstitial focal fibrosis. 
(and in places partially replaced them). Active fibroblasts, inflammatory cell elements were virtually absent. The average width of the endomysium was $5.630 \pm 0.130 \mu \mathrm{m}$, perimysium - $30.61 \pm 0.18 \mu \mathrm{m})$. In some cardiomyocytes their enlargement was noted, in others - compaction or enlightenment of the cytoplasm, fragmentation and defibering. Anastomoses between the fibers were moderate. The average diameter of cardiomyocytes was $10.61 \pm 0.21 \mu \mathrm{m}$, nuclei $-3.600 \pm 0.170 \mu \mathrm{m}$. In general, the myocardium retained its structural order. Its architecture was disturbed mainly due to focal fibrosis and edema of the interstitium (Fig. 7).

\section{Discussion}

Doxorubicin is an anthracycline drug and has been used as an antitumor agent in oncology for more than a decade [15].

Like most anticancer drugs, Doxorubicin, along with antitumor effects, has a toxic effect on vital organs, including the heart. Cardiotoxic effect is clinically manifested by the development of cardiomyopathy and congestive heart failure $[9,15,21]$.

The mechanism of cardiotoxic effects of Doxorubicin has not been fully studied. However, analyzing the literature, we can identify a number of links in the pathogenesis that are key in the development of toxic heart disease. These include oxidative stress, inflammation, apoptosis, mitochondrial dysfunction, and calcium overload of cardiomyocytes [3, 11, 19, 22].

All the described pathogenetic mechanisms depend on the concentration of the drug in the blood [14, 24]. It follows that the local supply of the drug to the tumor should not only provide maximum concentration and therapeutic effect in tumor tissues, but also reduce systemic toxic effects [8, 20].

Doxorubicin is one of the drugs successfully used in the treatment of bladder cancer [5]. At superficial localization of the process there are optimal conditions for local intravesical administration of chemotherapy. The introduction of the drug into the bladder is not technically difficult. Due to the morphological features of the mucous membrane, the absorption of the drug from the bladder cavity into the blood is minimal, which should reduce its toxic effects on the body as a whole and heart tissue in particular.

In general, analyzing the data obtained by histomorphological and histomorphometric examination of the myocardium, we can conclude that all animals of the experimental group had, first of all, circulatory disorders in the heart muscle at the level of hemomicrocirculation, which,

\section{References}

[1] Babjuk, M., Burger, M., Comperat, E.M., Gontero, P., Mostafid, A.H., Palou, J. ... Soukup, V. (2019). European Association of Urology Guidelines on Non-muscle-invasive Bladder Cancer (TaT1 and Carcinoma In Situ) - 2019 Update. European Urology, 76(5), 639-657. https://doi.org/10.1016/j.eururo.2019.08.016

[2] De Angelis, R., Sant, M., Coleman, M. P., Francisci, S., Baili, P., Pierannunzio, D. ... Capocaccia, R. (2014). Cancer survival in in turn, led to damage (in mainly - dystrophy), predominant malnutrition of cardiomyocytes, interstitial edema and fibrosis. When using the intravesical method of chemotherapy, at the end of the experiment, the animals histomorphologically preserved pathological changes in the myocardium (circulatory disorders with the phenomena of stromal and intracellular edema, pathologically altered cardiomyocytes, scattered lympho-histiocytic elements and focal fibrosis in the stroma) however, the degree of their expressiveness and prevalence was insignificant. At the end of the experiment, three of the four studied indicators differed significantly from similar indicators in the control group. Thus, the diameter of cardiomyocytes was significantly smaller, and the width of the endomysium and perimysia zones was significantly larger than normal. At the same time, the diameter of the nuclei of cardiomyocytes did not differ significantly from the values in the control group.

The presence of the above changes, such as hypertrophy of some cardiomyocytes on the background of their general malnutrition, interstitial fibrosis, along with macroscopic changes in the heart, give us reason to argue about the development (under the influence of chemotherapy) in experimental animals dilated cardiomyopathy. However, the normalization of the diameter of cardiomyocyte nuclei at the end of the experiment partially indicates the normal functional activity of cardiomyocytes. In addition, changes in the diameter of cardiomyocytes and the width of the endomysium and perimysia zones were less pronounced than the previously described changes in the myocardium of rats with systemic administration of Doxorubicin [7].

Collectively, the obtained data indicate a slight cardiotoxic effect of Doxorubicin during its intravesical administration, which, in general, correlates with the literature data describing the clinical efficacy of this method of administration [6]. However, in our opinion, for a more detailed assessment of the state of the myocardium, it is necessary to further investigate the dynamics of changes in the electrophysiological activity of the heart, as well as biochemical markers of its damage.

\section{Conclusions}

1. Serial intravesical administration of Doxorubicin in moderate therapeutic doses according to the proposed method causes changes in the myocardium of experimental animals which are partly similar to changes in the heart of people undergoing chemotherapy with this drug.

Europe 1999-2007 by country and age: results of EUROCARE-5-a population-based study. The Lancet. Oncology, 15(1), 23-34. https://doi.org/10.1016/S1470-2045(13)70546-1

[3] Diamanti, J., Mezzetti, B., Giampieri, F., Alvarez-Suarez, J. M., Quiles, J. L., Gonzalez-Alonso, A. ... Battino, M. (2014). Doxorubicin-induced oxidative stress in rats is efficiently counteracted by dietary anthocyanin differently enriched 
strawberry (Fragaria $x$ ananassa Duch.). Journal of Agricultural and Food Chemistry, 62(18), 3935-3943. https:/ /doi.org/10.1021/jf405721d

[4] Ferlay, J., Steliarova-Foucher, E., Lortet-Tieulent, J., Rosso, S., Coebergh, J. W., Comber, H. ... Bray, F. (2013). Cancer incidence and mortality patterns in Europe: estimates for 40 countries in 2012. European Journal of Cancer (Oxford, England: 1990), 49(6), 1374-1403. https://doi.org/10.1016/ j.ejca.2012.12.027

[5] Garcia, J. A., \& Dreicer, R. (2006). Systemic chemotherapy for advanced bladder cancer: update and controversies. Journal of clinical oncology : official journal of the American Society of Clinical Oncology, 24(35), 5545-5551. https://doi.org/ 10.1200/JCO.2006.08.0564

[6] Jin, X., Zhang, P., Luo, L., Cheng, H., Li, Y., Du, T. ... Gou, M. (2016). Efficient intravesical therapy of bladder cancer with cationic Doxorubicin nanoassemblies. Intern. J. of Nanomedicine, 11, 4535-4544. https://doi.org/10.2147/ IJN.S103994

[7] Kostiuk, O.H., Hodovan, N.L., Gormash, P.P., Taran, I.V., Grebeniuk, D.I., Mashevska, O.V. (2020). Dynamics of morphological changes in the heart of rats after serial systemic administration of Doxorubicin. Reports of Morphology, 26(4), 22-29. https://doi.org/10.31393/morphology-journal-202026(4)-04

[8] Laufer, M., Ramalingam, S., Schoenberg, M.P., Haisfield-Wolf, M.E., Zuhowski, E.G., Trueheart, I.N. ... Egorin, M.J. (2003). Intravesical gemcitabine therapy for superficial transitional cell carcinoma of the bladder: a phase I and pharmacokinetic study. Journal of Clinical Oncology: Official Journal of the American Society of Clin. Oncology, 21(4), 697-703. https:// doi.org/10.1200/JCO.2003.09.028

[9] Lehmann, L.H., \& Frohling, S. (2020). Mechanismen der Kardiotoxizitat onkologischer Therapien [Mechanisms of cardiotoxicity of oncological therapies]. Der Internist, 61(11), 1132-1139. https://doi.org/10.1007/s00108-020-00881-2

[10] Lenis, A.T., Lec, P.M., Chamie, K., \& Mshs, M.D. (2020). Bladder Cancer: AReview. JAMA, 324(19), 1980-1991. https://doi.org/ 10.1001/jama.2020.17598

[11] Mandziuk, S., Gieroba, R., Korga, A., Matysiak, W., JodlowskaJedrych, B., Burdan, F. ... Dudka, J. (2015). The differential effects of green tea on dose-dependent Doxorubicin toxicity. Food \& Nutrition Research, 59, 29754. https://doi.org/10.3402/ fnr.v59.29754

[12] Mar, N., \& Dayyani, F. (2019). Management of Urothelial Bladder Cancer in Clinical Practice: Real-World Answers to Difficult Questions. Journal of Oncology Practice, 15(8), 421-428. https://doi.org/10.1200/JOP.19.00215

[13] Nair, A.B., \& Jacob, S. (2016). A simple practice guide for dose conversion between animals and human. Journal of Basic and Clinical Pharmacy, 7(2), 27-31. https://doi.org/10.4103/ 0976-0105.177703

[14] Nebigil, C.G., \& Desaubry, L. (2018). Updates in AnthracyclineMediated Cardiotoxicity. Frontiers in Pharmacology, 9, 1262. https://doi.org/10.3389/fphar.2018.01262

[15] Pugazhendhi, A., Edison, T., Velmurugan, B.K., Jacob, J.A., \& Karuppusamy, I. (2018). Toxicity of Doxorubicin (Dox) to different experimental organ systems. Life Sciences, 200, 26-30. https://doi.org/10.1016/j.lfs.2018.03.023

[16] Sanli, O., Dobruch, J., Knowles, M.A., Burger, M., Alemozaffar, M., Nielsen, M. E., \& Lotan, Y. (2017). Bladder cancer. Nature Reviews. Disease Primers, 3, 17022. https://doi.org/10.1038/ nrdp.2017.22

[17] Schmidt, S., Kunath, F., Coles, B., Draeger, D.L., Krabbe, L.M., Dersch, R. ... Meerpohl, J.J. (2020). Intravesical Bacillus Calmette-Guerin versus mitomycin C for Ta and T1 bladder cancer. The Cochrane Database of Systematic Reviews, 1(1), CD011935. https://doi.org/10.1002/14651858.CD011935.pub2

[18] Siegel, R.L., Miller, K.D., \& Jemal, A. (2018). Cancer statistics, 2018. CA: a Cancer Journal for Clinicians, 68(1), 7-30. https:/ /doi.org/10.3322/caac.21442

[19] Sun, X.P., Wan, L.L., Yang, Q.J., Huo, Y., Han, Y.L., \& Guo, C. (2017). Scutellarin protects against Doxorubicin-induced acute cardiotoxicity and regulates its accumulation in the heart. Archives of Pharmacal Research, 40(7), 875-883. https:// doi.org/10.1007/s12272-017-0907-0

[20] Tyagi, P., Tyagi, S., Kaufman, J., Huang, L., \& de Miguel, F. (2006). Local drug delivery to bladder using technology innovations. The Urologic clinics of North America, 33(4), 519-x. https://doi.org/10.1016/j.ucl.2006.06.012

[21] van der Zanden, S. Y., Qiao, X., \& Neefjes, J. (2020). New insights into the activities and toxicities of the old anticancer drug Doxorubicin. The FEBS Journal, 10.1111/febs.15583. Advance online publication. https://doi.org/10.1111/febs. 15583

[22] Zhang, D., Yao, L., Yu, S., Cheng, Y., Jiang, J., Ma, Q., \& Yan, Z. (2020). Safety and efficacy of en bloc transurethral resection versus conventional transurethral resection for primary nonmuscle-invasive bladder cancer: a meta-analysis. World Journal of Surgical Oncology, 18(1), 4. https://doi.org/ 10.1186/s12957-019-1776-4

[23] Zhang, J., Cui, L., Han, X., Zhang, Y., Zhang, X., Chu, X. ... Chu, L. (2017). Protective effects of tannic acid on acute Doxorubicin-induced cardiotoxicity: Involvement of suppression in oxidative stress, inflammation, and apoptosis. Biomedicine \& Pharmacotherapy = Biomedecine \& Pharmacotherapie, 93, 1253-1260. https://doi.org/10.1016/ j.biopha.2017.07.051

[24] Zhao, L., \& Zhang, B. (2017). Doxorubicin induces cardiotoxicity through upregulation of death receptors mediated apoptosis in cardiomyocytes. Scientific Reports, 7, 44735. https://doi.org/ 10.1038/srep44735

[25] Zhou, Z., Zhao, S., Lu, Y., Wu, J., Li, Y., Gao, Z. ... Cui, Y. (2019). Meta-analysis of efficacy and safety of continuous saline bladder irrigation compared with intravesical chemotherapy after transurethral resection of bladder tumors. World Journal of Urology, 37(6), 1075-1084. https://doi.org/ $10.1007 / \mathrm{s} 00345-019-02628-7$

\section{МОРФОЛОГІЧНІ ЗМІНИ У СЕРЦІ ЩУРІВ ПРИ СЕРІЙНОМУ ВНУТРІШНЬОМІХУРОВОМУ ВВЕДЕННІ ДОКСОРУБІЦИНУ}

\section{Костюк О.Г., Годован Н.Л., Гормаш П.П., Таран І.В., Гребенюк Д.І., Машевська О.В.}

Поряд з вираженим протипухлинним ефектом Доксорубіцин спричиняє системний вплив із ураженням життєво важливих органів, зокрема серця. Це спонукає до пошуку способів попередження кардіотоксичного впливу препарату, одним із яких може бути внутрішньоміхурове його введення. Мета дослідження - розробити спосіб серійного внутрішньоміхурового введення Доксорубіцину у середньотерапевтичних дозах в експерименті та оцінити кардіотоксичний ефект препарату. До дослідження були включені 42 самки щурів лінії Wistar. Контрольну групу склали 7 інтактних щурів. Дослідну групу склали 35 щурів, котрим проводили внутрішньоміхурову хіміотерапію Доксорубіцином у дозі 5 мг/ка 1 раз на тиждень протягом 5 
тижнів. На 7, 14, 21, 28 та 35 добу вилучали серия дослідних тварин для морфологічного дослідження. Гістоморфометрично визначали: діаметр кардіоміоцитів (у серединній їх частині) і поперечний діаметр їх ядра, ширину інтерстиціального простору (ендо- та перимізія). Дані гістоморфологічного та гістоморфометричного дослідження міокарда свідчили про те, що у всіх тварин дослідної групи мало місце порушення кровообігу в серцевому м'язі на рівні гемомікроциркуляції. Такі зміни призводили до гіпотрофії кардіоміоцитів, інтерстиціального набряку та фріброзу. При проведенні внутрішньоміхурової хіміотерапії у тварин відмічалися виражені зміни міокарда, такі, як розширення зони ендомізію, за рахунок капілярного повнокрів'я та набряку, у порівнянні з тваринами інтактної групи. Наприкінці експерименту у тварин дослідної групи зберігалось розширення зони ендомізію в основному за рахунок інтерстиціального фріброзу. Подібні зміни вказують на гіпоксемію міокарда з ушкодженням та загибеллю кардіоміоцитів, активацією інтерстиціального та замісного колагеноутворення. Отримані морфологічні дані частково свідчать про розвиток у експериментальних тварин дилятаційної кардіоміопатії. Проте дані зміни були менш вираженими, ніж описані нами раніше зміни, що виникали після системного введення препарату. Додаткові дослідження електрофрізіологічної діяльності серия та біохімічних маркерів дозволять повною мірою оцінити ступінь кардіотоксичності Доксорубіцину при його внутрішньоміхуровому введенні. Таким чином, серійне внутрішньоміхурове введення Доксорубіцину у середньотерапевтичних дозах за запропонованою методикою викликає в міокарді експериментальних тварин зміни, котрі частково подібні до змін у серці людей, котрі отримують хіміотерапію даним препаратом.

Ключові слова: доксорубіцин, кардіоміопатія, морфологія, експеримент, щури, внутрішньоміхуровий. 